\title{
Natureza, ocupação territorial e vias de comunicação de Goiás nos relatos de viagens do século XIX
}

\author{
Nature, territorial occupation and means of communication in Goiás \\ in the nineteenth century travel narratives
}

\author{
FABÍULA SEVILHA DE SOUZA \\ Universidade Estadual Paulista | UNESP - FCL/Assis
}

\begin{abstract}
RESUMO Este trabalho objetiva analisar, em termos gerais, as elaborações discursivas acerca do mundo natural nos relatos de viajantes que percorreram Goiás no século XIX. Especificamente, visa a problematização das observações desses estrangeiros sobre a exploração da natureza, o povoamento, e o incremento do comércio e das vias de comunicação.
\end{abstract}

Palavras-chave Natureza - território - viajantes - Goiás.

\begin{abstract}
This work intends to analyze the discursive constructions about the natural world in the narratives from travelers who traveled over Goiás in the nineteenth century. It specifically aims at the questioning of these foreigners' observations about nature's exploitation, settlement, enhancing trade and means of communication.
\end{abstract}

Key-words Nature - territory - travelers - Goiás.

\section{Introdução}

A abertura do Brasil aos cientistas estrangeiros a partir do início do século XIX foi considerada como um movimento de "redescobrimento do Brasil". A célebre expressão cunhada por Sérgio Buarque de Holanda sintetiza o momento em que o Brasil foi alvo de inúmeras viagens e expedições científicas, com o objetivo de realizar o levantamento e a coleta de espécies animais, vegetais e minerais;" posteriormente classificadas, catalogadas e remetidas para os grandes herbários e museus de história natural da Europa. Esse reconhecimento científico do território compunha a política da Ilustração luso-brasileira que vinha sendo articulada desde fins do século XVIII.

No bojo do Século das Luzes emergiu uma nova concepção de ciência, acompanhada da retórica utilitarista e dos ideais de uma natureza dessacralizada, isto é, "um espaço aberto para pesquisas de todo o tipo, que a dissequem, expliquem, diferenciem, classifiquem". ${ }^{2}$ Concebê-la enquanto lugar neutro, destituído dos sacramentos divinos, abria caminho para que os homens se sentissem cada vez mais proprietários do espaço natural, despertando a vontade de conhecê-lo e dominá-lo. Paralelamente, ampliou-se a noção de espaço e alteridade com o desenvolvimento das ciências naturais e mecânicas, e com a Europa em contato crescente com a América, África e Ásia. 
Essas transformações têm raízes na Renascença e nas Grandes Navegações, mas somente no século XVIII reuniram-se as condições necessárias para colocar o saber científico em um novo patamar, a partir de então sistematizado e institucionalizado enquanto condição sine qua non para a soberania e legitimação simbólica dos nascentes Estados nacionais. Com efeito, o desenvolvimento das técnicas industriais implementadas na Europa impunha a necessidade de maximizar os rendimentos dos produtos vegetais e animais conhecidos e acessíveis aos europeus, bem como aumentar os mercados e as matérias-primas, de modo que, no decorrer do Oitocentos, as viagens científicas se avolumaram e assumiram uma função mais específica, fundamental no projeto expansionista e imperialista, na acumulação de capitais e na administração dos Estados nacionais.

De caráter marcadamente moderado e peculiar, o Reformismo llustrado luso-brasileiro baseou-se em um verdadeiro levantamento das riquezas e possibilidades do reino e da colônia. ${ }^{3}$ Esta última, por sua natureza opulenta, passa a ser vista como "tábua de salvação" ante a grave crise econômica por que passava o Reino Português. É a partir deste prisma, de intrínseca ligação entre política e negócios na exploração do mundo natural, que devemos encarar a abertura do território brasileiro a cientistas estrangeiros. Viajantes ingleses, como Henrique Koster, John Luccock, Maria Graham e John Mawe; franceses, como Jean Baptiste Debret, Nicolas-Antoine Taunay e Grandjean de Montigny; alemães, como o Barão von Eschwege e Georg Heinrich von Langsdorff, e, inclusive, luso-brasileiros, como Alexandre Rodrigues Ferreira, embrenharam-se pelos mais distantes caminhos do Brasil. ${ }^{4}$

0 Centro-Oeste, em comparação às zonas litorâneas e imediações - Rio de Janeiro, São Paulo e Minas Gerais, por exemplo -, foi alçado por um número menor de viagens e expedições científicas. A distância geográfica e as dificuldades de transportes obstaculizavam a incursão de viajantes por esta porção central do território luso-brasileiro, o que, porém, não impediu que renomados viajantes para aí se dirigissem. Em 1819, estiveram em Goiás o botâniconaturalista francês Auguste de Saint-Hilaire, o zoólogo Johann Baptist von Spix, o botânico bávaro Carl Friedrich Philipp von Martius, e o médico e botânico austríaco Johann Emanuel Pohl. Em 1840 e 1843, respectivamente, viajaram pela Província o médico e naturalista escocês George Gardner e o naturalista francês Francis Castelnau.

Seus relatos constituem-se em importantes fontes para a História Ambiental, preocupada em entender as relações entre sociedade e natureza, do plano mais físico e material ao intelectual e mental, enquanto processo histórico. ${ }^{5}$ Isto porque esses viajantes percorreram Goiás em um momento bastante elucidativo do ponto de vista da interação entre sociedade e natureza. No contexto global, esse processo é marcado pelo aumento da demanda de matéria prima para a nascente industrialização europeia. Em âmbito nacional, estabelecida a ruptura com Portugal, em 1822, o processo que se segue é o de fundação do Império do Brasil, sob a perspectiva de edificação de um vasto e poderoso império que, por sua privilegiada posição geográfica e exuberante natureza, seria portador de um futuro promissor no rol das grandes nações civilizadas. ${ }^{6}$ Regionalmente, a então capitania achava-se em processo de transição entre as atividades mineradoras, cujo declínio instensificou-se a partir de 1780, e a pecuária de exportação.

Nesse sentido, buscamos analisar as elaborações discursivas acerca do mundo natural nos relatos de viajantes que percorreram Goiás no século XIX, bem como problematizar as observações desses estrangeiros sobre a exploração da natureza, o povoamento e o incremento do comércio e das vias de comunicação. Partimos do pressuposto de que percorrer as linhas de desdobramento desse processo por meio das formas de ver, sentir e pensar o mundo natural ajuda-nos a compreender as transformações e os impactos do lugar da natureza na vida humana, e do papel da vida humana na natureza.

\section{A natureza sob olhar caleidoscópico}

0 novo, o fascínio da descoberta e a possibilidade de explorar o desconhecido serviam de molas propulsoras, animando-os a viajar em lombo de mulas, cercados de privações, pelas mais distantes regiões, enfrentando caminhos difíceis. Certamente, o contato com outros povos modificou a forma com que o homem enxergava a si próprio, o outro e o mundo. Não é menos verdadeiro, porém, que a leitura do espaço social e natural passava por um filtro configurado 
nos termos daquilo que esses viajantes entendiam como padrão, de modo que "há sempre uma comparação implícita do Brasil com o que no século XIX chamava-se 'países civilizados'. ${ }^{7}$ Isto implica considerar que o parâmetro de análise é de idealização do modelo europeu.

0 ambiente natural e as espécies com as quais se depararam ao longo da viagem pelo território goiano diferiam sobremaneira das que lhes eram familiares em seus países de origem. De algumas delas, até então, só tinham tomado conhecimento por meio dos livros de botânica e zoologia, ou de cronistas, muitos deles misturando elementos fantasiosos e mitológicos. À necessidade de ver com os próprios olhos somava-se a de estudar minuciosamente, do que resultava a correção de observações errôneas sobre plantas e paisagens, e mesmo a desconstrução de ideias preconcebidas de determinada espécie:

Faz-se geralmente idéia muito errada acerca da riqueza da flora das margens dos grandes rios da América. Nestas regiões [às margens do Araguaia], em que alternativamente se faz sentir a ação das correntezas mais violentas e, por ocasião da vazante, a dos raios directos do sol, geralmente só se encontra uma vegetação pobre e mirrada, mas extremamente compacta. É só algumas léguas para o interior, ou nos lugares nunca atingidos pelas enchentes, que se pode encontrar a vegetação activa e pujante que dá tanta magnificência às paisagens da América tropical. ${ }^{8}$

Entretanto, no conjunto, o ambiente natural era inteiramente novo. 0 processo de leitura, interpretação e descrição deste envolvia diferentes sentidos. Os fatores climáticos, perceptíveis fisicamente e de maneira instantânea, eram os que mais chamavam a atenção. A temperatura elevada na maior parte do ano, com dias quentes, noites geladas, inverno seco, má distribuição de chuvas e secas prolongadas, são características do bioma Cerrado que em nada lembravam o clima temperado europeu, com suas quatro estações bem definidas e temperaturas médias em torno de $10^{\circ} \mathrm{C}$. As queixas do "sol tórrido", "calor infernal" e "atmosfera abafada" de Goiás são constantes:

Embora a névoa atenuasse bastante os ardores do sol, fazia mais calor do que comumente viera fazendo desde meados de março, e por volta das três horas da tarde o termômetro marcava entre $31^{\circ}$ e $32,5^{\circ}$. Assim, ao chegarmos ali, estávamos todos afogueados (...) A escassez de água se fazia sentir de uma forma desesperadora. O céu mostrava-se sempre brumoso, mas apesar disso reinava um calor seco que causava um terrível mal-estar. ${ }^{9}$

Durante nossa estada, reinava em Contagem de Santa Maria [posto de fronteira entre Goiás e Minas Gerais] um calor fora do comum. No meio do dia, tinhamos $29^{\circ}$ até $30^{\circ} \mathrm{R}$; de manhã ao romper do dia, e ao pôr do sol, $18^{\circ} \mathrm{R}$; com isso, também estava a atmosfera no estreito e fundo vale completamente esfumaçada pelas queimadas, que devastavam os pastos e matagais das encostas próximas; e, à noite, soprava do sul um vento quente e violento, ao ponto de sacudir o telhado de nossa casa e não nos deixar dormir. Sentiamonos angustiados e incomodados (......10

(...) em 14 de janeiro, aventurei-me pelo mais longo [caminho], para a localidade de Bom Sucesso, quatro léguas distante de Meia Ponte. Ali chegamos esgotados pelo calor dos campos crestados e sofremos a maior privação. Não se podia obter alimento algum e, infelizmente, eu havia entregue ao tropeiro todas as minhas provisões e o baú com o dinheiro. Essa situação ainda mais se agravou com o frio que veio depois de uma violenta chuva e do qual não podia me defender por falta de cobertas ${ }^{11}$

A sensação térmica elevada era agravada pelos incêndios presenciados ao longo das viagens, razão de incômodo e angústia confessos. É interessante notar a frequência com que o tema das "queimadas" emerge. O elemento fogo, que hoje sabemos ser intrínseco e fundamental na estruturação de algumas paisagens do Cerrado, não aparece como algo natural, e sim como fruto da ação do homem:

Exceção feita dos vales chatos transversais, em que predominavam campinas e buritizais, ela [a Chapada do Paranã] é coberta totalmente com arbustos espessos em parte sem folhas durante a seca, que quase todos os anos são vítimas de fogo, posto pelos sertanejos. Justamente agora haviam se propagado essas queimadas numa extensão enorme, e nós éramos obrigados mais de uma vez a deixar o caminho, ou a 
passar apressadamente por entre trechos incendiados. Vento violento de nordeste levantava a poeira finíssima de carvão nos lugares queimados em enormes colunas, as quais moviam-se lentas e ameaçadoras em torno de nós; às vezes, cessando o vento, caíam como chuva negra, e escureciam o horizonte, no qual o sol poente parecia um grande raio. ${ }^{12}$

Em alguns pontos, viam-se ao longo algumas línguas de fogo e colunas de fumaça; os viajantes ateiam assim, todos os anos, fogo nos campos, com o intuito de aumentar-Ihes a fertilidade e preparar pastagens verdes para as caravanas subseqüentes. Percorremos desta maneira muitas e vastas extensões enegrecidas pelas queimadas. Essa operação modifica consideravelmente o aspecto da vegetação, porquanto muitas plantas só aparecem em semelhantes circunstâncias, bastando-lhes muitas vezes dois ou três dias para se desenvolver. ${ }^{13}$

As noções de dimensão conhecidas por esses viajantes são postas à prova mediante a comparação com 0 universo europeu - a exemplo do que faz Gardner com a extensão das matas da Grã-Bretanha e de Goiás, e Castelnau com os rios Araguaia e Sena. A exuberância da vegetação, muitas vezes de mata fechada, causava temor; os animais de grande porte eram descritos como selvagens; e o exotismo de muitas espécies impressionava tanto quanto os perigos que elas poderiam representar:

(...) vêem-se aqui e acolá grupos cerrados de palmeira-indaiá (Attalea compta). Elas formavam as primeiras matas de palmeiras a cuja sombra nos atrevíamos a passear a pé, em seco, e seguros de não toparmos com cobras gigantes nem jacarés. Os grandes cocos ricos de um óleo puro e gorduroso dessa palmeira [a Indaiá] fazem-na o pouso preferido das grandes araras-azuis (Ara hyacinthinus Lath), que voavam aos pares frequentemente acima de nossas cabeças. Tanto encanta a bela plumagem dessas aves, quanto doem nos ouvidos mesmo os mais insensíveis os seus guinchos roucos penetrantes, e certamente, se elas fossem conhecidas na Antiguidade, seriam tidas como portadoras de desgraça dos piores agouros. ${ }^{14}$

Neste rio [da Palma] como em todos os desta província [de Goiás] a enguia elétrica (Gymnotus Electricus) é muito comum: há-as de todos os tamanhos, desde um até seis pés de comprimento e deixam-se facilmente apanhar nos anzoes lançados para outros peixes. Comem-se às vezes, não sempre, embora se diga que sua carne é muito boa. Cavalos e homens, ao entrarem em contacto com elas, são frequentemente lançados ao chão pela descarga elétrica que delas recebem. Chamam-lhe os habitantes treme-treme. Em tempo de chuva os pescadores deste rio sofrem por vezes um choque que lhes vem através da umidade do caniço e da linha quando uma das enguias morde o anzol. Vi uma destas, cativa, de seis pés de comprimento, tão mansa, que deixava a gente passar-Ihe a mão e mesmo correr os dedos por seu corpo; mas, se a irritavam um pouco, beliscando-a, mesmo de leve, descarregava imediatamente seu choque elétrico. ${ }^{15}$

A descrição da paisagem aparece de maneira ambígua e interliga-se com a própria percepção da natureza. 0 deslumbre e o estranhamento mesclam-se e permeiam todos os relatos analisados com maior ou menor intensidade. Expressões adjetivas como "natureza majestosa" são muitas vezes seguidas de "extensões áridas" e "desérticas". As formas de ver, pensar e sentir o mundo natural devem, pois, ser contextualizadas, tanto em termos da formação intelectual e cultural, e dos próprios objetivos da estada, quanto das condições das suas viagens. Estes viajantes percorreram a lombo de burros por terrenos "íngremes" e "acidentados", de terras "montanhosas" e rochas "abruptas", seguidos por campos "salpicados de árvores", pastos "cobertos de subarbustos", campinas "batidas" e "caatingas". A esses homens de ciência, instruídos nos moldes da llustração europeia, expoentes de "uma ciência prática, voltada para a satisfação das necessidades das populações europeias e para o fortalecimento material e simbólico da nação que representavam" ${ }^{16}$ interessava antes a variedade de espécies a andar pelos extensos caminhos descampados, como os que thes eram apresentados em Goiás.

A impossibilidade, por fatores naturais característicos do ambiente goiano, como as vazantes dos rios ou a espessura das matas fechadas, de realizar os estudos a que se propunham acabava causando frustrações e a transferência de suas próprias inquietações quando da qualificação do cenário que visitavam. A descrição tende a ser mais positiva quando a coleta de espécies "úteis" e "interessantes" é feita a contento: 
Entre Mamoneiras e o Rancho do Guarda-Mor (...) Nada havia para ver, nem a mais humilde choupana, nem gado, nem caçadores, e no entanto não se podia dizer que aquelas solidões inspirassem melancolia, pois a luminosidade do céu bastava para embelezar tudo. Além do mais, o viajante encontra permanente distração nas singulares variações de vegetação, com suas maravilhosas diferenças de formas e de folhagem. Os trechos descampados, de terras baixas e úmidas, mostram-se pontilhados de buritis, que se elevam majestosamente a altura consideráveis. Finalmente, os morros vizinhos, com suas encostas cobertas de matas ou cumes rochosos talhados a pique, contribuem para modificar a cada momento a paisagem. ${ }^{17}$

A região aqui é de superfície ondulante, bem coberta de matas, embora a terra seja fraca, por muito arenosa. Durante estas viagens minhas coleções foram enriquecidas de muitos e belos exemplares de arbustos e plantas erbáceas; porque os campos arenosos e secos abundam em numerosas espécies de diplusodon, elegante arbustozinho de flores cor de rosa, além de que as porções de maior umidade me deram basta colheita de curiosas variedades de eriocaulon, bem pouco semelhante à nossa humilde espécie britânica, porque é alto e ramificado, e notável também pelos grandes e brancos tufos de flores que apresenta na extremidade. ${ }^{18}$

Ademais, faz-se necessário atentar para outros dois fatores que interferiam decisivamente nas condições e resultados das pesquisas: por um lado, a época escolhida para as viagens. Saint-Hilaire percorreu o território goiano durante a estiagem, entre maio e setembro, daí a visão muitas vezes depreciativa da vegetação e suas constantes menções a campos "crestados" e matas de "tom pardacento". Pohl, dentre os viajantes aqui analisados, o que teve a estadia mais longa em Goiás, por conta da estação chuvosa, decidiu esperar em Vila Boa por uma estação mais favorável às coletas e conservação de amostras para a História Natural. Já Castelnau, enfrentou o período das "chuvas torrenciais", queixando-se frequentemente dos "lamaçais e atoleiros" dos caminhos por onde passou.

Por outro, as diferenças e especificidades existentes entre uma porção e outra de um amplo território como 0 brasileiro. Saint-Hilaire, Pohl, Martius e Castelnau adentraram Goiás pelo sul. Não apenas já haviam conhecido a vegetação de São Paulo, Rio de Janeiro e Minas Gerais, como, tendo partido delas, ainda tinham vivas em suas memórias as lembranças visuais e físicas da Mata Atlântica. Na comparação feita com as matas litorâneas, a vegetação do Cerrado apresentava-se menos exuberante. As árvores de galhos retorcidos, 0 aspecto árido e agreste, a ausência de flores e os solos arenosos não causam, em um espírito de formação cultural moldada pelo Romantismo, a mesma sensação de deleite estético e emocional que uma natureza verdejante, pela qual demonstravam verdadeiro entusiasmo e fixação. Gardner, por sua vez, fez o caminho inverso. Saindo do Rio de Janeiro, visitou a Bahia, Pernambuco, Alagoas e Ceará, chegando a Goiás pelo norte da Província. Vinha, portanto, com o olhar e o organismo adaptados às características dos sertões e zonas áridas, o que lhe permitiu ter uma percepção mais positiva do Cerrado goiano.

Malgradas essas diferenças, os relatos têm como ponto convergente 0 fato de que o estranhamento frente ao desconhecido por vezes confundia-se em meio à opulência da fauna e da flora e, no imaginário desses viajantes, a natureza assumia feições pitorescas e hiperbólicas. A profusão de sentidos é caleidoscópica e disposta em um mosaico de sentimentos que se confundem na leitura do ambiente.

\section{A natureza generosa ou o germe da civilização ${ }^{19}$}

0 espírito filosófico que guiou esses viajantes foi a crença de que suas pesquisas e observações levariam ao progresso da Ciência e da Civilização, como bem sintetizado por Lorelai Kury na ideia de filantropia, entendida como

[...] uma virtude natural do ser humano, que é o amor por seu próximo. É em nome do progresso e do bem da humanidade que se dá a expansão colonialista do século XIX. Os viajantes europeus que visitam os países ditos selvagens ou menos civilizados, como é o caso do Brasil, sentem-se portadores de uma espécie de missão. Sentem-se como irmãos mais velhos dos outros povos, a quem devem ajudar e aconselhar. Para eles, seus interesses são os interesses da humanidade inteira. ${ }^{20}$ 
Observa-se, portanto, uma mentalidade utilitarista e racional com relação à natureza. Indicar as possibilidades de extração de matérias-primas dos gêneros dos reinos animal, vegetal e animal encontrados em Goiás era uma forma de colocar em prática a "missão" da qual se achavam incumbidos. As análises dos usos - medicinais, de subsistência e comerciável - das espécies, e das formas de cultivo e exploração são frequentes:

[...] no fim da estação das chuvas os campos se mostram alegremente adornados de duas elegantes espécies de callopisma; uma destas é mais abundante que a outra e, sendo muito amarga, é usada medicinalmente como genciana pelos habitantes de Goyaz: colhem-na quando em pleno florescimento e conservam-na seca em feixes que se vêem pendurados em quase todas as casas. É usado em infusão contra a dispepsia e também para fortalecer os convalescentes de febre. ${ }^{21}$

Os trabalhos [nas minas de sal] começam ordinariamente no mês de Agosto. Recolhem-se a princípio as camadas superficiais, que parecem as mais ricas, depositando-as em espécies de cochos de madeiras com dois ou três metros, sobre uma largura e uma profundidade de 30 a 35 centímetros, e com fundo crivado de orifícios. Derrama-se depois água na terra salina; o líquido se enche de sal e cai noutro cocho semelhante ao primeiro, situado em baixo. Esta solução é levada depois para ferver em caldeiras, tendo-se o cuidado de ir retirando toda a espuma que se acumula na superfície. Mergulham-se então na salmora grandes colheres em cujo fundo, ao cabo de uma hora, se deposita o sal em pó. Este sal, que é amargo e deve conter provavelmente cloreto de magnésio, é destinado aos animais. Quando cessa a formação deste depósito, mesmo no fundo da caldeira, já então retirada do fogo e posta sobre estacas de madeira, é o líquido decantado no tanque dito de esfriamento, onde então, por meio da lenta evaporação do sol, se formam os cristais cúbicos de um sal próprio às preparações culinárias, chamadas no país sal de pedra. ${ }^{22}$

Para fins explicativos, os relatos analisados podem ser divididos em dois blocos: 0 composto por Saint-Hilaire, Martius e Pohl, que se insere no período inicial de transição, compreendida aqui como uma reorganização do ecossistema para fins agrícolas, ${ }^{23}$ entre as atividades de mineração e a pecuária de exportação em Goiás; e o constituído por Gardner e Castelnau, que corresponde ao momento em que essa mudança ganha contornos mais nítidos.

Quando o primeiro grupo visitou Goiás, o cenário de opulência do auge da mineração ainda era um contraponto muito presente e a acomodação econômica à pecuária dava seus primeiros passos, influenciando na percepção de miséria, decadência geral e ausência de produtividade relatadas. A eles importava apontar os motivos para o declínio da mineração, bem como os produtos e os meios pelos quais os habitantes de Goiás podiam melhor aproveitar os recursos que a natureza Ihes fornecia. Saint-Hilaire e Pohl atentam em vários momentos para as "vastas solidões" de terras "mal cultivadas" e "incultas", que fortaleciam a ideia de ociosidade e contribuíam para a dita decadência da Província de Goiás:

Entre Lajes e Corumbá a região não muda, a não ser que se vê nas encostas dos morros um grande número de capoeiras. Em parte alguma se avista um pé de milho, de arroz ou de algodão, e as terras ao redor de Corumbá não aparecem mais cultivadas do que os lugares mais distantes de qualquer povoação. O caminho é tão pouco transitado que à beira dos riachos o capim-gordura fez desaparecer qualquer traço dele. ${ }^{24}$

Para abrir um buraco, empregam-se, aqui, três homens! Um segura e dirige um perfurador, o segundo bate nele com um martelo e o terceiro deita água sobre a pedra (...). Embora a terra vegetal de toda a região seja saturada de ouro, a ponto de, nessa exploração, um dia de trabalho de um homem produzir 4 a 6 vinténs de ouro (160 a 240 réis), os habitantes acham-se tão habituados a grandes lucros que, apesar de sua indigência, preferem um trabalho incerto, cansativo e pesado, a se satisfazerem com esta extração cômoda e segura, mas pequena. ${ }^{25}$

Em contrapartida, o segundo grupo depara-se com um cenário de expansão das fazendas de plantação e, sobretudo, de criação de gado. Em seus relatos, o foco recai sobre os aspectos ligados à produção e ao seu escoamento, assim como ao lugar de cultivo e à opção por este ou aquele gênero: 
Os habitantes do distrito [de Riachão] são tão desesperadamente preguiçosos, que mal plantam qualquer coisa suficiente à sua própria alimentação, posto que cada família tenha à disposição terras ilimitadas para plantar [...] O dono da casa onde paramos disse-me que não podia criar gado aqui por causa da devastação dos morcegos nos bezerros, de modo que ele era obrigado a tê-los longe dali, em lugar mais baixo da região. ${ }^{26}$

(...) como o solo é fértil e suas terras bem irrigadas, muito se prestam ao cultivo da cana-de-açúcar, de que há várias plantações. Da maior parte desta cana se faz cachaça. Também o arroz e a mandioca aí se produzem copiosamente. Toda a propriedade possuída pelo tenente Lagoeira cobre uma área de sessenta e quatro léguas quadradas: está dividida em várias fazendas de criação de gado, contendo cerca de quatorze mil cabeças, para serem vendidas a boiadeiros que os levam para Baía. ${ }^{27}$

(...) o lugar parecia sem recursos e não dispúnhamos senão da quantidade de víveres exatamente necessários para chegar a Salina. O medo dos selvagens oferece aos moradores ótimas razões para não se ocuparem com a agricultura, não sendo pois de admirar as dificuldades com que conseguimos prover a nossa matalotagem do que era essencial, comprando aos habitantes os poucos víveres de que dispunham e que seria mais prudente guardar para seu uso particular. ${ }^{28}$

Em que pesem os diferentes contextos, fato é que, entre ambos os grupos, pode-se pontuar um denominador comum: a recorrência não só às vantagens econômicas das produções naturais para o "progresso" da humanidade, mas também a uma intrínseca ligação entre a ideia de Civilização e de exploração racional da natureza. Essas questões podem ser apreendidas em suas observações acerca da ocupação do território e das vias de comunicação.

A própria configuração territorial goiana parece conter as razões para a sua "decadência" e "penúria" em meio à "opulenta natureza":

Em toda parte, na Europa, a proximidade das cidades é anunciada por um número crescente de habitações e por lavouras mais bem cuidadas. O mesmo acontece nas cidades do litoral do Brasil, cuja localização foi previamente determinada por ser favorável ao comércio e à agricultura. Nas regiões auríferas, os arraiais e cidades foram construídos onde o ouro era mais abundante, sendo esse o fator determinante na sua fundação. Sob outros aspectos, porém, a sua localização se mostra - como acontece com Vila Rica (Cidade de Ouro Preto) e Vila Boa - a mais desfavorável possível. O sistema de agricultura dos brasileiros não permite o cultivo de outras terras senão daquelas onde há matas. Em consequência, os campos vizinhos de Vila Boa, beirando a estrada de Mato Grosso, permanecem despovoados. ${ }^{29}$

À fartura de terras é atribuída a pecha de limitadora da prosperidade da agricultura na região, e encorajadora dos enormes vazios demográficos que caracterizavam a província:

Entre Lajes e Corumbá a região não muda, a não ser que se vê nas encostas dos morros um grande número de capoeiras. Em parte alguma se avista um pé de milho, de arroz ou de algodão, e as terras ao redor de Corumbá não aparecem mais cultivadas do que os lugares mais distantes de qualquer povoação. O caminho é tão pouco transitado que à beira dos riachos o capim-gordura fez desaparecer qualquer traço dele. ${ }^{30}$

Nesse ínterim, a "abundante" hidrografia da região, composta por dois grandes rios - Tocantins e Araguaia -, e por diversos rios menores, como o Rio Paranaíba, Rio Verde, Rio Aporé, Rio das Almas, Rio dos Couros, Rio das Antas, Rio dos Bois, Rio das Velhas e Rio Vermelho,ganha destaque como forma de diminuir as distâncias dos mercados consumidores e baratear os custos da produção. Os viajantes não deixaram de frisar as dificuldades que a navegação nos cursos d'água da província oferecia:

Pela via fluvial do Rio Tocantins, que desde 1773 pôs em comunicação esta província com a do Pará, dista ainda cem léguas. Partindo dali chega-se à cidade do Pará, em 15 até 18 dias; e, navegando rio acima, gasta-se um mês na viagem [...] essa navegação é particularmente penosa pelas inúmeras "itaipavas", 
pelas corredeiras e pequenas quedas do rio, as quais, em diversos pontos, como por exemplo as Cachoeiras de Santo Antonio, Itaboca e Praia Grande, obrigam a descarregar parte ou todo o carregamento; em outros sítios, como em Repartimento, Água de Saúde, Cajueiro e Tauiri, tornam necessário aliviar as canoas. Perigosa torna-se a viagem por causa das doenças como a febre intermitente, nervosa ou septicemia, e desinterias, que acometem frequentemente a equipagem, sobretudo ao norte da reunião do Tocantins com o Araguaia, e por causa da hostilidade dos índios ali residentes. ${ }^{31}$

Durante as cheias esses rochedos [do Araguaia] estão inteiramente cobertos; mas na época da seca formam pequenas cascatas, às vezes perigosas. Neste caso, experimenta-se a corredeira, permanecendo-se fora da corrente; depois, conhecida a passagem, lança-se a canoa com a máxima velocidade permitida pelos remos. O essencial é mantê-la perfeitamente no eixo da correnteza, sem o que na certa soçobrará. As embarcações passaram sem acidente, mas a ubá encalhou numa pedra produzindo tamanho choque que os seus dois tripulantes foram lançados n'água. ${ }^{32}$

A despeito dos obstáculos, porém, esses rios "caudalosos" e de "braços largos" eram vistos como um "facilitador":

A Província de Goiás é cortada por grandes rios, e o principal deles, o Tocantins, é facilmente navegável. Para dar escoamento aos produtos da região bastaria mandar construir algumas barcas, instalar às margens dos rios, de espaço a espaço, uma espécie de armazém onde se vendessem víveres e estabelecer postos militares na vizinhança. O governo já percebeu as vantagens desse plano e há bastante tempo vem concitando os habitantes de Goiás a se cotizarem para que seja usado o transporte fluvial. Mas eles são tão pobres que ninguém se apresentou como acionista. ${ }^{33}$

Indo além, o Tocantins e o Araguaia emergem como a única alternativa viável para uma exploração da natureza que fosse verdadeiramente racional, rentável e, portanto, destinada à exportação:

A criação de gado é a ocupação mais comum dos fazendeiros, porque o gado é de venda fácil no mercado da Baía. Mas em geral cultivam também um pouco de cana-de-açúcar, principalmente para a fabricação de cachaça, largamente consumida em todas as classes da sociedade e por isso mesmo de grande procura. Também se cultiva a mandioca, o arroz e o milho, tanto para consumo da casa, como para venda na vila. Todas essas plantações, porém, se fazem nas terras baixas [...] Tanto o solo como o clima se prestam bem ao cultivo do café, porque as poucas plantações dele feitas dão boa safra, mesmo sem terem recebido o mínimo cuidado [...] Nunca, porém, poderá ser aqui cultivado em grande escala para fins de exportação, por causa da grande distância do litoral. O Rio Tocantins oferece a única possibilidade de transporte fluvial e este é, por enquanto, apenas navegado por pequenas embarcações. ${ }^{34}$

A viagem que íamos empreender poderia não só ser útil à ciência, como trazer também à província benefícios reais. Dois grandes rios, o Tocantins e o Araguaia, quais vastas artérias, percorrem o território de Goiás, reunindo-se no extremo norte [...] Sob todos os pontos de vista, o Araguaia é uma via de comunicação muito superior ao primeiro, visto como, por intermédio do Rio Vermelho, começa a ser navegável já a quatro léguas da cidade de Goiás. Sua largura é, aliás, muito maior do que a do Tocantins, ao mesmo tempo que existem menos cachoeiras. Entretanto, temor exagerado dos selvagens que lhe assolaram as margens repetidas vezes, fez com que se abandonasse a sua navegação desde muitos anos. Também, se a administração dessas longínquas províncias pouco esforço faz para incrementar os meios de exportação, não se lhe pode pelo menos censurar a antipatia que demonstrara o governo português por tudo quanto tendesse a estreitar as relações entre as diversas províncias do Brasil..$^{35}$

Para estes viajantes, era mister compreender as razões pelas quais uma natureza vista como tão rica não levasse a região à prosperidade que julgavam adequada, ou seja, à um ideal de Civilização talhado à imagem e semelhança do modelo europeu de sociedade. Tal visão é representativa do pensamento dos sábios do século XIX, segundo o qual 0 mundo natural deveria ser dominado pela ciência, "a serviço da humanidade" e para o "progresso da nação". ${ }^{36}$ 


\section{Considerações finais}

A análise das elaborações discursivas acerca da natureza goiana nos relatos de viagem do século XIX permitiu pinçar elementos significativos para a compreensão das condutas e políticas de uso e aproveitamento de seus recursos. Chama a atenção o fato de que, mesmo implicitamente, havia a noção de que aquele ambiente formava um bioma diferenciado, com características peculiares. Observamos, porém, que a diversidade de formações vegetais não necessariamente indicava um aspecto favorável. A concepção de abundância esteve mais ligada às formações florestais densas. As vegetações rasteiras, galhos retorcidos, árvores de folhas ressequidas e coloração acinzentada, típicas de Cerrado, enganam um primeiro olhar e nos são apresentadas como algo menor, concepção esta que persiste ainda hoje.

No pólo oposto, a própria ideia de opulência é sintomática e deve ser problematizada. Como dito anteriormente, as viagens científicas tinham, dentre outras, a função de coletar e estudar espécies variadas que pudessem fomentar a produção de matérias-primas para a Europa. 0 sentido da exploração da natureza no século XIX era, pois, eminentemente econômico, pautado nos pressupostos do capitalismo mercantil e ancorado na maximização da produção e na lucratividade em curto prazo. A localização central de Goiás era estratégica para o Estado nacional brasileiro. Mantê-la articulada à dinâmica do restante do Império apresentava-se como condição sine qua non para a salvaguarda de fronteiras e a manutenção dos vínculos provinciais com o núcleo de decisões instalado no Rio de Janeiro, do qual dependia, ainda, a contiguidade territorial, base do poder centralizado.

A importância dessas observações descritivas e críticas extrapola o período em que foram produzidas. Esses relatos foram fundamentais na moldagem da percepção do que seria 0 ambiente natural e social goiano - e, em termos mais gerais, brasileiro. 0 Cerrado foi, durante muito tempo, considerado pela opinião pública e pelos próprios ecologistas como a "prima pobre" dos biomas, ${ }^{37}$ o que pode ter contribuído para a sua ocupação predatória. Do mesmo modo, a imagem de um país de riquezas naturais em contraste com as mazelas da sociedade, bem como de certo condicionamento do ambiente na definição do caráter humano, presentes nas descrições dos viajantes, encontra eco nas imagens estereotipadas que povoam o imaginário coletivo e circulam ainda hoje nos mais diversos seguimentos culturais. ${ }^{38}$

A natureza de Goiás, embora "generosa" e "pitoresca", emerge nos relatos de Saint-Hilaire, Martius, Pohl, Gardner e Castelnau como um obstáculo a ser transposto; um entrave ao povoamento, à civilização, à sociabilidade, à "boa índole do povo goiano", ao "florescimento do comércio" pelas dificuldades de transporte em um terreno "longínquo", "vasto" e irregular, cujos rios deveriam tornar-se navegáveis, "grandiosas vias de comunicação", mediante esforços humanos. Seguindo esta lógica, e diante da propalada riqueza, dever-se-ia tirar o maior proveito possível dos recursos naturais do Cerrado goiano.

0 fio de continuidade entre passado e presente pode ser facilmente detectado. Com a mecanização da agricultura, 0 incremento dos insumos agrícolas e as tecnologias empregadas no campo, a barreira da dita pobreza dos solos do bioma Cerrado foi vencida. As perspectivas atuais de um mercado receptivo e favorável à elevação da produção e do consumo de biocombustíveis, requisitando a ampliação das áreas destinadas ao cultivo da cana-de-açúcar, soja e milho, tendem a agravar o processo histórico de desmatamento e avanço desordenado sobre a vegetação nativa do Cerrado goiano.

\section{Notas e referências bibliográficas}

Fabíula Sevilha de Souza é mestranda em História e Sociedade pelo Programa de Pós-Graduação em História da Universidade Estadual Paulista (UNESP - FCL/Assis) e bolsista da Fundação de Amparo à Pesquisa do Estado de São Paulo (FAPESP). E-mail: fsevilhas@yahoo.com.br.

1 HOLANDA, Sérgio Buarque de. A herança colonial, sua desagregação. In: HOLANDA, Sérgio Buarque de. (Org.) História geral da civilização brasileira. São Paulo: Difel, 1975.

2 LAHUERTA, Flora Medeiros. Viajantes e a construção de uma ideia de Brasil no ocaso da colonização (1808-1822). Scripta Nova: Barcelona, 2006.

3 Ver: Aspectos da llustração no Brasil. In: DIAS, Maria Odila Leite da Silva. A interiorização da metrópole e outros estudos. São Paulo: Alameda, 2005. p. 49.

4 Sobre Viajantes, ver: BELUZZO, Ana Maria de Moraes. O Brasil dos viajantes: um lugar no universo. São Paulo: Fundação Odebrecht, Metalivros, 1994; 
LISBOA, Karen Macknow. A Nova Atlântida de Spix e Martius: natureza e civilização na viagem pelo Brasil (1817-1820). São Paulo: Hucitec/FAPESP, 1997; OBERACKER, Carlos. Viajantes, naturalistas e artistas estrangeiros. In: HOLANDA, Sérgio Buarque de (Org.). História geral da civilização brasileira. São Paulo: Difel, 1962; PRATT, Mary Louise. Os olhos do Império: relatos de viagem e transculturação. Bauru: Edusc, 1999. egundo Donald Worster, essas preocupações levam-nos aos três níveis de análise a que a História Ambiental tem se dedicado. São eles: $1^{\circ}$ ) entendimento dos aspectos orgânicos e inorgânicos da natureza; $\left.2^{\circ}\right)$ o domínio sócio-econômico da relação sociedade-natureza, que comporta as ferramentas de trabalho, relações de poder, modos de vida e produção; e $3^{\circ}$ ) as interações intelectuais e mentais, as formas de ver, sentir e pensar o mundo natural. Ver: WORSTER, Donald. Para fazer História Ambiental. Estudos Históricos, Rio de Janeiro:, FGV, v. 4, n. 8, p. 198-215, 1991. YRA, Maria de Lourdes Viana. A utopia do poderoso império. Portugal e Brasil: bastidores da política (1798- 1822). Rio de Janeiro: Sete Letras, 1994.

KURY, Lorelai. Viajantes e naturalistas do século XIX. In: PEREIRA, Paulo Roberto (Org.). Brasiliana da Biblioteca Nacional - Guia de fontes sobre o Brasil. Rio de Janeiro: Fundação Biblioteca Nacional/Nova Fronteira, 2001. p. 59

CASTELNAU, Francis. Expedição às regiões centrais da América do Sul. São Paulo: Cia Editora Nacional, 1949. p. 281 (Coleção Brasiliana, 266).

SAINT-HILAIRE, Auguste de. Viagem à Província de Goiás. Belo Horizonte/São Paulo: Itatiaia/Edusp, 1975, p. 121/122.

SPIX; MARTIUS. Viagem pelo Brasil: 1817-1820. Belo Horizonte/São Paulo: ItatiaiaEdusp, 1976. p. 101.

POHL, Johann Emanuel. Viagem no Interior do Brasil. Belo Horizonte/São Paulo: Itatiaia/Edusp, 1976. p. 117.

SPIX; MARTIUS, 1976, op. cit., p. 96.

CASTELNAU, 1949, op. cit., p. 241

SPIX; MARTIUS, 1976, op. cit., p. 93.

GARDNER, George. Viagens no Brasil: principalmente nas províncias do Norte e nos distritos do ouro e do diamante durante os anos de 1836-1841. Rio de Janeiro: Cia Editora Nacional, Biblioteca Pedagógica Brasileira, Coleção Brasiliana, 1942. p. 293.

KURY, Lorelai. Auguste de Saint-Hilaire: viajante exemplar. Revista Intellèctus, Rio de Janeiro, UERJ, 2004, vol. I., ano II.

SAINT-HILAIRE, 1976, op. cit., p. 87.

GARDNER, 1942, op. cit., p. 317.

Fazemos aqui alusão às palavras de Saint-Hilaire. "(...) quanto seria de desejar que uma administração sábia e inteligente despertasse finalmente de sua apatia os seus habitantes e os estimulasse a fecundar, pelo trabalho, os germes da prosperidade que uma Natureza generosa semeou à sua volta". SAINTHILAIRE, 1976, op. cit., p. 125.

KURY, Lorelai, 2004, op. cit., p. 66.

GARDNER, 1942, op. cit., p. 306.

CASTELNAU, 1949, op. cit., p. 261.

Adotamos a concepção de sistema agroecológico proposta por Donald Worster, que consiste em um ecossistema organizado para propósitos agrícolas, com 0 objetivo de "servir exclusivamente a um conjunto de propósitos conscientes, muitas vezes localizados fora dele - a saber, a alimentação e a prosperidade de um grupo de humanos". Ver: WORSTER, Donald. Transformações da Terra: para uma perspectiva agroecológica na história. Ambiente \& Sociedade, Campinas, v. 6, n. 1, p. 23-44, 2003.

SAINT-HILAIRE, 1976, op. cit., p. 32.

POHL, 1976, op. cit., p. 149.

GARDNER, 1942, op. cit., p. 321.

GARDNER, 1942, op. cit., p. 294.

CASTELNAU, 1949, op. cit., p. 249.

SAINT-HILAIRE, 1976, op. cit., p. 90.

SAINT-HILAIRE, 1976, op. cit., p. 32.

SPIX \& MARTIUS, 1976, op. cit., p. 98.

CASTELNAU, 1949, op. cit., p. 295

ALMEIDA, Coronel João Rodrigues Pereira de apud SAINT-HILAIRE, op. cit., p. 125.

ARDNER, 1942, op. cit., p. 304.

CASTELNAU, 1949, op. cit., p. 235

A este respeito, ver: KURY, Lorelai. "Viajantes e naturalistas do século XIX". In: PEREIRA, Paulo Roberto (Org). Brasiliana da Biblioteca Nacional - Guia de fontes sobre o Brasil. Rio de Janeiro: Fundação Biblioteca Nacional/Nova Fronteira, 2001; e LISBOA, 1997, op. cit.

Basta lembramos que, ao contrário do Cerrado, a Mata Atlântica já constava na Constituição de 1988 como patrimônio nacional.

Inúmeros são os exemplos deste Brasil sob a ótica estrangeira, tanto na Literatura quanto no Cinema. Convém aqui lembrarmos os mais recentes. No primeiro segmento temos 0 livro "The Testament" do norte-americano John Grisham. Escrito em 1999, o romance tem grande parte de sua história ambientada no Pantanal mato-grossense, para onde uma das personagens, Rachel Lane, mudou-se com o intuito de trabalhar com os "índios selvagens", nos termos do autor. Nesse ínterim, ela, que era filha ilegítima do falecido bilionário Troy Phelan, tornou-se herdeira de toda a sua fortuna. 0 advogado, Nate O'Riley, mesmo temendo deparar-se com canibais e anacondas, foi enviado à "selva" pantaneira incumbido de encontrá-la. Sem conseguir convencê-la a aceitar a herança e tendo contraído dengue, retorna aos Estados Unidos. Após um acordo com os herdeiros legítimos, o advogado faz uma segunda viagem ao Brasil, mas descobre que Lane havia falecido vítima de malária. Já na linguagem cinematográfica, poderíamos citar "Rio", animação em 3D de 2011, que conta a história de uma arara-azul (macho) levada para o Rio de Janeiro para acasalar com uma fêmea, mas que acaba se apaixonando e fugindo para não ser contrabandeada por uma cacatua. Doenças tropicais, natureza como intrínseca ao ethos brasileiro, exotismo; seja pelos relatos Oitocentistas, pelo viés trágico do romance ou pela fantasia do cinema, ainda é esta a imagem que persiste.

[ Artigo recebido em 10/2011 | Aceito em 04/2012 ] 